(C) 2019 Zhizhko, de la Cruz. This article is distributed under the terms of CC Attribution-Share Alike 4.0 International as described at https://creativecommons. org/licenses/by-sa/4.0

UDC: 37(73)"1501/1550":2-752

\title{
EDUCATION OF THE FRANCISCAN FRAILS IN THE THEOLOGICAL SCHOOLS AS BACKGROUND OF THEIR LEARNING IN THE AMERICAS (FIRST HALF OF THE XVI CENTURY)
}

\author{
Elena Zhizhko \\ PhD and Doctor in Science hab., Full prof, \\ Autonomous University of Zacatecas, Mexico, \\ https//orcid.org/0000-0001-9680-8247; e-mail:eanatoli@yahoo.com \\ Delfina de la Cruz \\ EDD Student, \\ Autonomous University of Zacatecas, Mexico, \\ e-mail: celiyaz.2003@gmail.com
}

This article presents the results of the historical-pedagogical study, which goal was to inquire about the previous knowledge and ways of learning of the missionaries who worked in New Spain in the first half of the XVI century (in particular, the Franciscans), to understand the process of their appropriation of Nahuatl and creation of religious texts in this language. The authors found through the documentary-bibliographic study that the Franciscan friars, who travelled to the American missions, undoubtedly belonged to the educated elite of the moment and were carriers of innovative linguistic ideas and well ahead of their time (perception of the language as the object of the study, creation of the grammar Universalis). Candidates should be intellectually prepared and experienced in missionary practice with infidels that represented to have the openness and ease to learn the languages and customs of the conquered peoples, such as great courage to face sacrifice and even death. Likewise, the analysis carried out showed that the first Franciscan missionaries, who arrived in the New World, were trained in European religious, educational institutions. At the end of their studies, the friars were individuals, who held a broad spectrum of knowledge in rhetoric, philosophy, theology, as well as the mastery of several languages. This formation helped them acquire Amerindian languages, in particular, their studies of rhetoric and Latin directly served them to learn indigenous languages (notably, Nahuatl). It is also important to note that although the structure of Latin is different from the structure of Nahuatl, knowledge of rhetoric was supportive for missionaries in creating Nahuatl grammars. 
Key words: Franciscan frails' education in the first half of the XVI century; European theological schools; the process of the appropriation of Amerindian languages, in particular, Nahuatl, in New Spain; missionaries' previous knowledge and ways of learning; the role of linguistic and rhetoric knowledge for Nahuatl acquisition.

У иій статті представлені результати історико-педагогічного дослідження, метою якого було дізнатися про способи набуття знань у релігійних європейсъких навчальних закладах католицькими місіонерами (зокрема, францисканцями), які працювали $b$ Новій Іспанї $b$ першій половині XVI століття, щуоб зрозуміти процеси уособлення індіансъких мов та створення релігійни текстів ицми мовами. Шляхом Виконаного документально-бібліографічного дослідження автор виявив, що фрранцискансъкі монахи, які подорожували до американських місій, безсумнівно, належали до освіченої еліти того часу $і$ були носіями інноваційних лінгъістичних ідей, що значно випереджали свій час (сприйняття мови як об'єкта дослідження, створення граматики Universalis та ін.). Кандидати повинні були мати навички для вивченні мов та звичайв завойованих народів, бути інтелектуально підготовленими та досвідченими у місіонерській практиці з неВірними, мати Велику сміливість, бути готовими до жертв та навіть смерті. Проведений аналіз показав, що перші франиисканські місіонери, які прибули до Нового Світу, пройшли навчання $b$ європейсъких релігійних навчальних закладах. Закінчивии навчання, монахи були людъми, які володіли широким спектром знань з риторики, філософрї, теології, латинської мови, а також навичками оволодіння кількома європейськими мовами. Така підготовка допомагала їм оволодіти американськими мовами, зокрема, мовою нагуатль. Важливо також зазначити, щуо хоча структура латинсъкої мови відрізняється від структури мови нагуатль, знання з риторики допомагали місіонерам у створенні периих граматик мови нагуатль.

Ключові слова: освіта франиисканиів у першій половині ХVI століття; Європейсъкі богословські школи; прочес засвоєння американських мов, зокрема, мови нагуатль, у Новій Іспанії; попередні знання та способи навчання місіонерів; роль лінгвістичних та риторичних знань для оволодіння мовою нагуатль.

Introduction. In the sixteenth century, two dissimilar cultures were found in the Americas: Nahuas (and many more Native Americans groups) and Spanish (Christian Europeans), each with its different worldview. In this cultural clash, two different languages that do not match their phonetic, grammatical, morphological, syntactic structures were faced. From the beginning, oppositional features appear in both cultures, and a syncretic process of evolution and involution has emerged and has marked indigenous peoples. The ways of apprehending the world of the Other and of "narrating" it were different, as was the communicative model: oral in one group (in Nahuatl - tlatoani) and written in the other (in Spanish - Escribano). It caused 
great difficulty both for the natives to learn Spanish, and for the evangelizing friars ${ }^{1}$ To master local languages (in particular, Nahuatl), causing problems of misinterpretation, distortion of concepts and meanings, misunderstanding of the Other.

Hence, the importance of approaching the roots of the "disagreement" that occurs in the sixteenth century in the New Spain, one of which is linguistics by the incommensurability of the Latin/Spanish and Nahuatl languages, each with its way of thinking and organize the world, and with different conceptual frameworks. Besides, it should be noted that the learning of the friars of the Nahuatl language occurred from the set of knowledge, skills and experience they possessed, having acquired and practised during their formal studies in seminars and convent schools in Europe, as well as their informal learning of medieval European values and culture in general.

The purpose of the article. The goal of this work is to inquire about the previous knowledge and ways of learning of the missionaries (in particular, the Franciscans) from a documentary-bibliographic study, in order to understand the process of their appropriation of Nahuatl and creation of religious texts in this language.

Literature review. Various international researchers (Torre-Revello, 1962; Esteve-Barba, 1964; Konetzke, 1972; Prat-García, 1985; Borges-Morán, 1986, BriceñoPerozo, 1987; Martinell-Gifre, 1988, 1992; Baudot, 1990; Bayle, 1992; Gambra, 1992, Maeztu, 1992; Suárez-Roca, 1992; Polanco, 2000; Brain, 2010; among others) dedicated their works to the study of the causes, effects and consequences of the encounter of two cultures (European through the Spanish and American through the numerous indigenous ethnic groups). Also, many Mexican researchers worked on the topics of confrontation of two different worldviews from the conquest of the New World: O'Gorman, 1971; Kobayashi, 1974; Villoro, 1987; Gonzalbo, 1990, Tanck-de-Estrada, 1985; 2000; Bracamonte, 1994; Bazant, 1996; León-Portilla, 1991; 2002; Flores-García, 1999; 2016; Muñoz-García, 2005; Murillo-Gallegos, 2009; 2010; 2012; Morquecho, 2010; Guzmán and Cervantes-Guzmán, 2012; Hernández-de-León-Portilla, 2002; 2014, among others).

It is essential to point out that most researchers focus their attention on the problem of learning Spanish by the indigenous people. It turns out that there are few works on the subject of indigenous languages' learning by the evangelizing friars. This topic was investigated by De-la-Garza, 1992; Duverger, 1996; Máynez, 1999, Brain 2010; Guzmán, Cervantes-Guzmán, 2012; Murillo-Gallegos, 2010; 2012; among others.

Results. It is essential to clarify that of the Catholic orders of the 16th century (Augustinian, Dominican, Jesuit), the Franciscans were the first to arrive in the New World. In 1523, the three Flemish Franciscan friars arrived: Pedro de Gante, Juan de Tecto and Juan de Aora, then came to the twelve Franciscans led by Fray Martin de Valencia, known as the "twelve apostles". Studies testify that between the sixteenth and eighteenth centuries, 7250 priests, 287 students and 287 Franciscan legos arrived

\footnotetext{
${ }^{1}$ It is worth clarifying, that in contrast to a priest empowered to celebrate the sacraments and Divine worship, to preach the Gospel, a friar in the Middle Ages was religious belonging to one of the mendicant orders. On the other hand, unlike the monks, the friars were not attached to a single convent but were part of an organized group. Also, they had different votes and restrictions from those of the monks and spent more time abroad in contact with people, instead of being held in a convent (Merino-Abad, 1993, p. 60).
} 
in New Spain, predominantly theology students (but there were also arts and philosophy students) (Borges, Morales, 1993, pp. 131-133).

This fact is fundamental for the election of this religious order for the analysis, which results are presented below. On the other hand, in the study carried out, such aspects were considered as:

1. The Franciscan friars were representatives of several countries/kingdoms/towns (Castilian, Aragonese, Catalan, Flemish, French) being educated in Latin and obtained their "linguistic formation" (mostly in Europe), who learned Nahuatl language naturally living together (often for long periods) with the Nahuas.

2. Although in this process a particular cultural-linguistic immersion occurred, the friars were interested only in learning those aspects of the language that could allow them to create religious texts in Nahuatl.

3. There were variants of Nahuatl, and the religious texts created contained the elements of at least two to three variants.

Thus, the fact that most of the first Franciscan missionaries had their "grammatical formation" in Europe confirm the investigations of Gemelli (1940), Merino-Abad (1993), Mollat (1996), Roest (2000), Breva-Claramonte (2008), CaroRivera (2010), among others. According to Breva-Claramonte (2008), in the be-ginning, "These [the friars] used to travel to the Colony between the ages of 19 and 30 and, sometimes, even higher, once they had received a religious and humanistic formation in the colleges and universities". However, "[...] over the years, schools, language schools, seminars, universities were founded, and the first printers were in-stalled in America (in Mexico in 1540 and Peru in 1580), so that their [of the friars] trai-ning continued in the Colony; moreover, some of them were already born in coun-tries where indigenous languages were spoken" (Breva-Claramonte, 2008, p. 26).

Therefore, we can mention two types of younger brothers' formation: the one received in Europe and the one acquired by the Creoles in the educational institutions of the Franciscan Order in New Spain. For the period at hand, the first half of the sixteenth century, it is necessary to delve into the analysis of the first.

In general, the teaching for Christian clerics was born in Europe in the II-IV centuries along with the Christian philosophy that the apologetic Fathers develop in defence of Christianity (Gadotti, 2003, p. 60). In the fourth century, Fathers of the Christian Church Saint Gregorio (330-389), Saint Basilio (329-379), Saint Jerome (347420) and Saint Augustin (354-430) establish and impose a body of doctrines, dogmas, cult and discipline of the Christian religion. They create in theological schools the humanistic and philosophical-theological teaching for clergy, through the studies of the seven liberal arts: the trivium (grammar, dialectic and rhetoric) and the quadrivium (arithmetic, geometry, astronomy and music), and the demand for humility through oaths to Christian fidelity and vows of obedience, poverty and chastity (Abbagnano, Visalberghi, 1992, p. 96).

In this curriculum, grammar deals with language study and rhetoric serve to move listeners in order to persuade them of the truth. This program culminated in the study of theological and philosophical problems, considered by Saint Augustine as a process of formation and purification, thanks to which the soul becomes capable of capturing the divine Unity of the world and the underworld (Abbagnano, Visalberghi, 1992, p. 101). 
In the VIII-XI centuries, marked by the development of feudalism and the crusades, the monastic schools predominated but, gradually, they were surpassed by the cathedrals. In the transition from the twelfth to the thirteenth centuries, the product of his time, Saint Francisco appears (Giovanni Bernardone, 1181-1226), a key character for the development of Christian philosophy. For him, the human value of the poor became sacred due to the model of Christ, attribute previously reserved only to monks²; and for the creation of a new theological vision of the poor, of misery, of the need for charity as a means of salvation. The Franciscans proposed a way of life-based on thought and very innovative way of acting for that time.

It is essential to point out that the Franciscans adopted the educational model of the Dominican Order. However, although their teaching system is the modified version of that of the Dominicans, in essence, these two religious orders differ by initiating the first one "movement in order to cause fundamental changes in the hearts of Christians", and the second was instituted as the main anti-heresy force in southern France (Roest, 2000, p. 5). At first, the formal organization of the studies did not concern the Franciscan leaders. Everything they had to know was contained in the Regula Bullata (1223), the Franciscan ideal of poverty and the obligation to attract through their exemplary life the infidels to Christianity.

However, between 1223-1229, the first Franciscan "houses of study" arise: that of Bologna (1223), that of Montpellier and Toulouse (between 1225 and 1227), that of Oxford (1224), that of Paris (1224). Apart from these large essential schools, elementary theological schools are established in many Italian provinces, in southern France, in England and some German cities: Hildesheim (1225), Magdeburg (1228) (Roest, 2000, p. 7). In these schools, the study was always seen according to the evangelizing mandate of the Church.

The Franciscan preparation took place in two stages: In the first, the religious was formed in the foundations of religious life, the knowledge of the order, the Regla (Rule), the Constitutions, the ascetic life; in the second, if he aspired to the presby-terate, he would have to study philosophy and theology that would enable him. However, the preparation did not end there, and he should be open to expanding his knowledge. In religious formation, the novitiate began. At this stage, the individual faced the personal encounter with God, with the brothers and with himself; it lasted one year, and he lived in the novitiate house, totally oblivious to the outside world, where he would combine work with study, prayer and interpersonal encounter (Gemelli, 1940, p. 10).

Thus, in the thirteenth century, the Franciscan School of Philosophy and Theology emerges, which most famous actors were Alejandro de Hales, Juan de la Rochela, Saint Buenaventura, Juan Duns Escoto and Guillermo de Ockham, representatives of Latin Augustinianism and Aristotelianism. In their works, they developed the central precepts, under which subsequent generations of Franciscan friars and novices were formed. Thus, in Summa fratris halensis Alejandro de Hales (1185-1245) postulates that wisdom is aimed at God, and is expressed in the contemplation of prayer; science aims at reason, but is ordered to contemplation (wisdom); philosophy is the ansilla

\footnotetext{
${ }^{2}$ It should be noted that the monks were a way of life that emerged at the beginning of Christianity, men and women who moved away from the world to live in contemplation and praying continuously. Unlike priests, monks did not function as intermediaries between God and man (Gemelli, 1940, pp. 5-6).
} 
of theology, part of an experience of faith (crede ut intellegas, according to St. Augustine) and aims at the things of this world (Roest, 2000, p. 9).

Likewise, Saint Buenaventura (Juan Fidanza, 1217-1274) in his texts Itinerarium mentis in Deo (Itinerary of the mind towards God), Sentencias, Breviloquio (textbook for students), the University Sermons or Collations, on the one hand, follows the idea of St. Francisco that his followers should not be priests and preach with words, but with the example. At the same time, since by then, there were more than 80 thousand Franciscans, Saint Buenaventura orient them to studies, to the priesthood (devote themselves to teaching, parishes, catechesis). He unites mystical theology (the study of God) with dogmatic theology (study of things, nature), science with wisdom, affirming that there are two means of following Christ: through asceticism and penance, and through study, means of sanctification and spirituality. He elaborates the norms and laws through which the convents are governed; enters the controversy between secular and mendicants, seeking to find the Theology of poverty in St. Francisco, mark course in Franciscan studies (Mollat, 1996, p. 13).

Another theorist of Franciscan philosophy, Juan Duns Escoto (1266-1308) in his works Ordinatio (Opus oxoniense), Reportata parisiensa (Opus parisiense), Treaty of the First Principle, establishes that theology is not a theoretical science, valid in itself. However, a practical science destined to teach men the end, to which they are ordered and the means to achieve it. Unlike Buenaventura, following Aristotelia-nism and the materialist current more, he explains the knowledge of the truths and universal essences through abstraction and intuition, he does not admit that knowledge comes from an interior illumination. However, that love guides intelligence to the truth.

So, the teaching of the Franciscan friars was based mainly on the Regula Bullata (1223) with its principles of living as the poorest and preaching by example, forming humanity in the image of Christ, with the force of love for God and his fellowmen. At the same time, its practical philosophical and theological content was complemented by the ideas of St. Francisco's followers.

The primary strategy of the Franciscans to fulfil their objective was the missions (missionary means: envoy, mediator, developer, guide). In the likeness of Jesus Christ, who sent his apostles to save the world, the Church sends its members to the announcement of Jesus Christ and the Gospel, promotion of religious values and guidance for salvation (missions to Egypt, Tartary, Armenia, Persia, Mesopotamia, China, India, Bosnia, Serbia, Bulgaria, Romania, Lithuania, Holy Land). A Franciscan missionary was a preacher, whose scope of action was the urban or rural environment with an already Christianized population (important missions) and missions among the infidels to achieve their conversion to Christianity (Gemelli, 1940, p. 104).

The organization of the Franciscan "study system" occurs after the elaboration of the Constitutions "Prenarbonenses" and "Narbonenses", which are the norms emanating from the General Chapter of Rome of 1260 and accentuate the cultural and scientific criteria in the selection of candidates and place substantial restrictions on the acceptance of illiterate brothers in the Order (Iriarte, 1979).

From the Constitutions of Assisi of 1316, the organization of the Franciscan educational system was practically concluded: in all parts of Europe with the influence of the younger brothers, and there was a network of hierarchically 
structured schools. Many convents or hostels of friars in different provinces had studia particularia. These "houses of lawyers" had different levels: studia grammaticalia, studia artium, studia philosophiae, studia sollemnia theologiae. Also, each province (in total 34) had to send a certain number of its friars to studia generalia to get involved in the most advanced studies of theology. Some of these higher schools had a direct connection with the theological faculties of the universities of Paris, Oxford and Cambridge and could grant their students the title of magisterium theologiae. The most prominent of the Franciscan studium generale was the University of Paris. Annually, the minor friars had to present to this university a candidate to obtain the degree of Baccalaureus Biblicus and one of Baccalaureus Sententiarum (after studying two years and concluding the four-year post-sentencing practices) (Roest, 2000, p. 11).

Therefore, the Franciscan ecclesiastical teaching comprised three levels of logical, philosophical and theological studies: elementary (studia particularia), middle (studia phisicae and philosophiae) and higher (studia generalia). At first, illitera-te friars were not considered to devote themselves to studies, however, with the admission of novices 12-13 years of age, there was a need to institute elementary art schools where grammar, logic, philosophy and theology were taught. Thus, the Chapter of Paris (1292) establishes that provincial ministers must provide studia artium to young people at the custodial and provincial levels. So a convent was designated in each custody that had to receive and prepare the novices from there the network of custodial schools or studia particularia. There was also supervision, and regular reports of the implementation of what was established and the progress of the students were presented. It should be noted that these schools were attended not only by Franciscan novices but also by oblate children, even 6-8 years old (Roest, 2000, p. 65).

In the process of this elementary instruction, the most outstanding young people were chosen to continue their preparatory studies (studia phisicae and philosophiae), and then enter the higher reading courses. In this educational level that lasted two-three years, the friars learned the liberal arts: advanced logic, natural philosophy, metaphysics and moral philosophy. Also, some other students went on to study arts: advanced grammar, rhetoric, logic, and prepared for theological and pastoral practices within the province. Some students were chosen to perform more practical functions in the convents. The guardians of the convents where the custodial schools were located, were dedicated to taking care of the discipline and exhorting all the members of the convent to attend classes as many times as possible (Roest, 2000, p. 67).

Therefore, in the fourteenth-fifteenth centuries, the Franciscan educational system had a stable and well-organized structure. The preparation of the younger brothers, both ecclesiastical and intellectual of very high quality for the time, was the primary issue of the order. During the sixteenth century in Europe, the Franciscans had defended themselves, while supporting the Church against Protestantism, by returning to the austerity of its origins, neglecting the studies. In such a way that the seventeenth century represented passing again from "[...] the sancta rusticita [the saint stupid] to know, joining the rigor of the ancient spiritual, the study of the books of the great medieval masters [...]: San Buenaventura and Juan Duns Escoto" (Gemelli, 1940, p. 170). The edition and reprint of the Omnia Opera gave a boost to the escotista 
studies, mainly in Spain, Italy and France. With the escotista studies, the idea of the Royalty of Christ and the campaign in favour of the Immaculate Conception of Mary was renewed, turning it into theological weapons.

Regarding their linguistic training, European missionaries knew Latin grammar, their mother tongues and some of Greek. At that time, Latin was the language of culture, of science and the Church, the gateway to the study of grammar, rhetoric and logic. Religious learned to speak and write Latin through the many practical grammars that circulated throughout Europe, above all, with the help of the Introductiones latinae (1481) by Antonio de Nebrija (1444-1532). This work included notional general definitions of the parts of the sentence and their accidents and placed determined emphasis on the study of the formal elements that corresponded to these notions. The Latin grammar of Nebrija was a standard treaty in Spanish universities (Breva-Claramonte, 2008, p. 30).

Therefore, the missionaries trained in the European intellectual framework, where it was believed that Latin enjoyed more prestige than other languages and that it was more similar to the natural order or to what should have been the first languages, consciously or unconsciously followed the model of Latin grammar. In this model, the analysis of languages was

[...] of double slope: the universal or rational slope and the slope of the use or manifestation of the universal in the particularisms of each language. It is the logicist model, on which traditional grammar is based, which has its roots in the philosophy of Plato, Aristotle and scholastic grammar; the latter suffered the influence of the Thomistic theory of knowledge that separated the levels of the sensitive world and the intelligible world (Breva-Claramonte, 2008, p. 3).

This dispute between the universals and the nominalists, for whom the language had no special significance (it was a flatus voci, that is, a sound of the voice that designated particular objects and not universal realities), generated in the thirteenth and fourteenth centuries so-called Modistae or "speculative grammarians" movement. Linguistic School Modistae tried to compile the living languages that existed, to propose a "grammar universalis", in which the essential ontological categories that are based on the linguistic systems of the different existing languages could be discovered. In the words of Caro-Rivera (2010),

These considerations led to take seriously the meanings that were created in the language when establishing an objective relationship with reality, since the modi essendi, which are objectively existing qualities, were understood in the modi intelligendi, the significant objects of the representation of the understanding, which were meanings in grammar, modi significandi. [...] These significant systems had to account for the metaphysical categories implicit in the language; all living languages had a common root, at least that was the starting hypothesis. The processes, by which contact with reality was achieved, should be observed in all existing language structures (p. 11). 
Consequently, at the end of the Middle Ages, the language was the object of ontologization. Extreme realism establishes language in the world, along with other things, and signs it as an object of knowledge. According to Foucault (Foucault, 2002, p. 38), " [...] the sixteenth century superimposed semiology and hermeneutics on the figure of similarity. To search for meaning is to bring to light what resembles. To look for the law of signs is to discover similar things. The grammar of beings is their exegesis.

Moreover, the language they speak, says nothing more than the syntax that links them" 3 .

Thus, the Franciscan friars, who arrived in New Spain, were trained in the context of the linguistic ideas described above and under their influence they undertook the titanic work of creating the grammars of the Amerindian languages, in particular, of Nahuatl. Likewise, missionaries trained in Europe had reliable tools to learn indigenous languages and create their grammars. Also, when they arrive in the New World, they establish educational institutions for both the peninsular and the Indians, similar to the Franciscan European schools, with the same curriculum and textbooks, thus spreading the transforming ideas of the world.

Conclusions. Therefore, the documentary-bibliographic study carried out allows us to conclude that the Franciscan friars, who travelled to the American missions, undoubtedly belonged to the educated elite of the moment and were carriers of innovative linguistic ideas and well ahead of their time (perception of the language as the object of the study, creation of the grammar universalis). Candidates should be intellectually prepared and experienced in missionary practice with infidels that represented "[...] the most excellent work, and there should be no excuse for ignorance of the language or fear of danger. There should only be a great love and trust of God and great courage to face sacrifice and even death" (Merino, 1993, p. 84); "[...] a missionary must know the language, religion, superstitions and customs of the country to be evangelized (Sahagún, 2003, pp. 49-53).

Likewise, the analysis carried out showed that at the end of their studies, the friars were individuals, who held a broad spectrum of knowledge in rhetoric, philosophy, theology, as well as the mastery of several languages. This formation helped them acquire Amerindian languages, in particular, their studies of rhetoric and Latin directly served them to learn indigenous languages. It is also important to note that although the structure of Latin is different from the structure of Nahuatl, knowledge of rhetoric was supportive for missionaries in creating Nahuatl grammars.

These grammars or arts were written for the sole purpose of evangelizing the Indians, creating ecclesiastical texts. Hence the learning of Nahuatl through sui generis, atypical, selective linguistic immersion also, since linguistic concepts do not match in one language or another (for example, the concepts "soul", "bread", "hell", "sin"), the friars used different linguistic strategies for the creation of ecclesiastical texts in Nahuatl: resemantization, domestication, linguistic loans, neologisms, search

\footnotetext{
${ }^{3}$ In the same work, Foucault explains that language works as a mark of things, as a kind of signal that establishes similarity. Hence, to name things is to discover the name they have inscribed on them. The similarity calls for similarity, entangling itself in an endless circle of objects that one by one has a name, a property, signs that discover their meaning while they are being investigated, making the reality that is inscribed in them emerge.
} 
for direct equivalents or through analogies in their own culture or known cultures, quotes in Latin with the subsequent explanation in Nahuatl, disrupting and simplifying Nahuatl original and devising an ecclesiastical Nahuatl, technical language to evangelize, also originating the "Christianization of Nahuatl".

Further research. The following investigations will be dedicated to the study of these processes of contemplation, abstraction, deliberation, introversion of the Nahuatl culture and language and creation of their grammars. In particular, the attitude of the friars towards indigenous languages and their learning will be investigated.

\section{References:}

Abbagnano, N., \& Visalberghi A. (1992). Historia de la pedagogía [History of pedagogy]. Traducción Jorge Hernández Campos, México: FCE.

Borges, P., \& Morales, F. (1993). "Los hermanos menores en las Provincias de América, Su procedencia geográfica [The brothers minor in the provinces of America, their geographical origin]. In F. Morales (Ed.), Franciscanos en América, Quinientos años de presencia evangelizadora [Franciscans in America, Five Hundred Years of evangelizing presence] (pp. 131-133). México, Conferencia franciscana de santa María de Guadalupe.

Breva-Claramonte, M. (2008). El marco doctrinal de la tradición lingüística europea y los primeros misioneros de la Colonia [The doctrinal framework of the European linguistic tradition and the first missionaries of the Colony]. Bulletin hispanique, 110-1, 25-59. https://doi.org/ 10.4000/bulletinhispanique.431.

Foucault, M. (2002). Las palabras y las cosas [The words and the things]. Buenos Aires: Siglo XXI.

Gadotti, M. (2003). Historia de las Ideas Pedagógicas [History of Pedagogical Ideas] (4th ed.). México: Siglo XXI.

Gemelli, A. (1940). El franciscanismo [Franciscanism] (3rd ed.). Traducción Gil Monzón, OFM, Barcelona: Luis Gili Editor.

Iriarte, L. (1979). Historia franciscana [Franciscan history]. Madrid: Editorial Asís. Retrieved from http:// www.franciscanos.org/historia/Iriarte-HistoriaFranciscana-08.htm.

Merino J. A. (1993). Historia de la filosofía franciscana [History of Franciscan philosophy]. Madrid: Editorial Cisneros.

Mollat, M., \& Rubial, A. (1996). La hermana pobreza, El franciscanismo de la Edad Media a la evangelización novohispana [The Franciscanism of the Middle Ages to the evangelization of New Spain], México: Facultad de Filosofía y Letras, UNAM.

Rivera, C., \& Gabriel, J. (2010). “La domesticación de las lenguas. De las gramáticas europeas a las gramáticas amerindias (de 1492 al siglo XVIII)". Mutatis Mutandis, 3(1), 3-29.

Roest, B. (2000). A history of Franciscan education (c.1210-1517). Leiden; Boston; Koln: Brill.

Sahagún, F. B. de (2003). Historia General de las cosas de la Nueva España [General History of the things of New Spain], Tomo I, Madrid: Dastin. 